\title{
PENDIDIKAN DAN PEMBELAJARAN DIMASA PANDEMI COVID 19
}

\author{
Nama Penulis : NURDIN
}

Email : nurdin.kayla@gmail.com

UNIVERSITAS ISLAM AL - IHYA KUNINGAN

\begin{abstract}
ABSTRAK
Pandemic COVID-19 telah mengubah berbagai aspek kehidupan manusia saat ini, khususnya dalam dunia pendidikan. Ini mengharuskan semua elemen pendidikan untuk beradaptasi kebiasaan Baru ( $A K B)$ Pembelajaran online menjadi solusi efektif untuk mengaktifkan kelas meski sekolah telah ditutup mengingat waktu dan tempat menjadi beresiko pada masa pandemic ini. Namun, teknik pembelajaran ini penting untuk dievaluasi sesuai dengan kondisi setempat mengingat sebaran fasilitas dan kemampuan orang tua memberikan fasilitas pembelajaran online berbeda kepada peserta didik di Indonesia.
\end{abstract}

\begin{abstract}
The COVID-19 pandemic has changed various aspects of human life today, especially in the world of education. This requires all elements of education to adapt to new habits (IMR). Online learning is an effective solution to activate classrooms even though schools have closed considering that time and place are at risk during this pandemic. However, this learning technique is important to be evaluated according to local conditions considering the distribution of facilities and the ability of parents to provide different online learning facilities to students in Indonesia.
\end{abstract}

Kata Kunci : Pembelajaran, Masa Pandemi COVID - 19 


\section{PENGANTAR}

Dalam kondisi darurat ini, kemasan muatan pembelajaran Belajar Dari Rumah ( BDR ), seharusnya akan sarat dengan penguatan literasi dan karakter. Konten diajarkan, selain untuk mengembangkan pengetahuan siswa (rote learning), juga digunakan sebagai medium dalam menumbuhkan dan memperkuat kemampuan literasi dan karakter. Sebagai sebuah aktivitas pembelajaran formal, penilaian tetap harus dilakukan. Namun, penilaian BDR dilakukan bukan untuk menentukan standar pencapaian (attainment level) atau kepentingan nilai (assigning grade) semata. Penilaian dalam BDR dilakukan mestinya dengan tujuan untuk membantu siswa agar dapat menemukan cara belajar yang lebih baik bagi dirinya pada setiap subjek yang dipelajari/diajarkan. Penilaian semacam ini disebut dengan penilaian formatif, yakni skor/nilai hasil sebuah aktivitas penilaian bukanlah standar pencapaian ataupun tujuan proses pembelajaran. Karena jika kita menggunakannya sebagai tujuan proses pembelajaran, nilai sesungguhnya yang merupakan ukuran dari status pembelajaran akan hilang dan justru mendistorsi proses pembelajaran yang diharapkan (Rogertitcombe: 2015).

Untuk tujuan ini, berbagai metode penilaian bisa digunakan, baik berupa penilaian proyek, penilaian portofolio, extended essays, dan bentuk penilaian lainnya yang relevan dengan tujuan pembelajaran. Teknologi pembelajaran Pengalaman pengelolaan pendidikan dalam kondisi darurat sekarang ini, hendaknya dapat menumbuhkan kesadaran kolektif kita sebagai bangsa akan pentingnya teknologi pembelajaran guna mewujudkan pendidikan bermutu dan berkeadilan. Konsep cyber schools dan/atau blended learning, termasuk penilaian disruptif (disruptive assessments), yang sudah banyak digunakan pada sejumlah sekolah/perguruan tinggi di mancanegara, hendaknya dijadikan kajian serius, konsisten, dan terukur oleh para pengendali kebijakan pendidikan pada tingkat nasional dan daerah. Kenyataan, beberapa akademisi akan memiliki kesempatan untuk secara kritis terlibat dalam teori, penalaran pedagogis dan desain pembelajaran yang terkait dengan pendidikan daring dan jarak jauh ini. Sementara itu, guru juga sudah perlu untuk melakukan perbaikan dengan cepat sehingga tak lagi gagap dan memungkinkan pembelajaran daring dan jarak jauh dapat berjalan sebagaimana layaknya.

Menyelenggarakan pendidikan daring dalam banyak kasus masih berupa kuliah atau seminar, dengan melibatkan kelompok-kelompok besar individu, semua menghadiri ruang yang sama, pada saat yang sama, tetapi mereka tidak serta-merta terlibat satu sama lain. Pengajaran yang lebih baik melibatkan penilaian formatif, dan ini tidak harus ditandai dengan kerja keras. Teknik mempertanyakan, baik sinkron dalam hal streaming jarak jauh maupun asinkron dalam fasilitasi berbasis teks, yang memberikan bukti kepada guru/dosen untuk merespons dan menunjukkan arah pembelajaran bisa jauh lebih berharga.

Pembelajaran selanjutnya melibatkan siswa berkomunikasi satu sama lain, dengan kegiatan terstruktur antara mode transmisi, kolaborasi dan aplikasi. Ini semua bisa terjadi menggunakan teknologi yang tersedia sekarang dengan platform live-casting, dokumen kolaboratif, ruang dan aplikasi bersama (Matt Cornock: 2020).

Keadaan terkini dari teknologi informasi dan komunikasi tidak secara otomatis menciptakan lingkungan belajar yang inovatif dan berkualitas. Untuk membenarkan penggunaannya di kelas, mereka perlu menambahkan nilai dalam bentuk pada peningkatan motivasi dan keterlibatan siswa. 


\section{PEMBAHASAN}

Kehidupan manusia begitu berubah drastis dikala diuji oleh sang Pencipta,akan kehidupan social yang begitu dalam keadaan normal dari segala bidang bisa berjalan tanpa ada hambatan apapun baik dari segi bidang sosial, Ekonomi, Politik Budaya maupun Pendidikan namun kehidupan yang normal tersebut berubah ketika adanya peristiwa yang menggerkan dunia yaitu peristiwa Covid - 19.

Pendidikan merupakan kunci pembangunan sumber daya manusia. Kualitas sumber daya manusia merupakan kunci terwujudnya Indonesia Emas 2045, yang adil dan sejahtera, aman dan damai, serta maju dan mendunia. Pendidikan yang akan menentukan kemana bangsa ini akan menyongsong masa depannya, apakah menjadi bangsa besar yang beradab, cerdas dan siap beradaptasi dengan perubahan zaman. Atau, menjadi raksasa sakit, yang tenggelam dalam berbagai persoalannya sendiri.

Pada Bulan Desember 2019 Muncul kasus pneumonia yang tidak dketahui tepatnya di kota Wuhan, China kasus tersebut diakibatkan oleh Virus Corona atau yang dikenal dengan COVID 19 ( Corona Virus Desese-2019 ) arakteristik virus ini adalah kecepatan penyebaran yang tinggi yang menyebar diseluruh dunia yang telah menjadi Pandemic Global. Virus Corona juga telah mewabah di Indonesia sejak awal Maret hingga saat ini Yang tersebar diseluruh Kabupaten Kota di Indonesia.

Dampak yang ditimbulkan dari pandemic COVID - 19 telah mengubah berbagai aspek kehidupan manusia. Kisah wabah ini dapat memiliki akhiran yang berbeda pada setiap Negara (Lee, 2020) yang bergantung pada kebijakan yang diterapkan dan ketanggapan pemerintah guna meminimalisir penyebarannya. Berbagai kebijakan telah dikeluarkan oleh pemerintah Indonesia untuk mengurangi tingkat penyebaran virus corona dengan memberlakukan social distancing, physical distancing hingga pemberlakuan PSBB (Pembatasan Sosial Bersekal Besar), PKKM ( Pemberlakuan Pembatasan Kegiatan Masyarakat ) pada beberapa daerah.

Kebijakan - kebijakan yang dikeluarkan untuk membatasi penyebaran COVID - 19 berdampak pada berbagai bidang diseluruh dunia khususnya pendidikan di Indonesia. Wabah COVID - 19 mendesak pengujian pendidikan jarak jauh hampir yang belum pernah dilakukan secara serempak sebelumnya (Sun etal., 2020) Pendidikan Jarak Jauh ( PJJ ) atau BDR ini merupakan ujian bagi semua elemen pendidikan yakni Pemerintah, peserta didik, guru hingga orang tua. Mengingat pada masa pandemic, waktu, lokasi dan jarak menjadi permasalahan besar saat ini (Kusuma \&Hamidah, 2020). Sehingga pembelajaran jarak jauh ( PJJ ) atau Belajar Dari Rumah ( BDR ) online menjadi solusi untuk mengatasi kesulitan dalam melaksanakan pembelajaran secara tatap muka langsung.

Ini memberikan tantangan kepada semua elemen dan jenjang pendidikan untuk mempertahankan kelas tetap aktif meskipun sekolah telah ditutup. Krisis kesehatan yang diakibatkan oleh wabah COVID - 19 telah mempelopori pembelajaran online secara serempak. Badai pembelajaran online telah terjadi hampir diseluruh dunia selama pandemi COVID - 19 (Goldschmidt \& Msn, 2020). Guru dan pendidik sebagai elemen 
penting dalam pengajaran - besaran yang belum pernah terjadi sebelumya dari pendidikan tatap muka tradisional ke pendidikan online atau Pendidikan Jarak Jauh (Bao, 2020; Basilaia \& Kvavadze, 2020). Ini didukung dengan perkembangan teknologi yang tidak terbatas pada revolusi industry 4.0 saat ini. Pembelajaran online secara efektif untuk melaksanakan pembelajaran meskipun pendidik dan peserta didik berada di tempat yang berbeda (Verawardinaetal.,2020). Ini mampu menyelesaikan permasalahan keterlambatan peserta didik untuk memperoleh ilmu pengetahuan. Pandemic COVID -19 secara tiba - tiba mengharuskan elemen pendidikan untuk mempersipakan itu semua.

Dalam pendidikan ini sekolah dituntut untuk mempunyai formula strategi juga model pembelajaran yang begitu perlu pemikiran yang betul betul menyesuaikan dengan keadaan salah satunya adalah dengan adanya perubahan Metode dengan cara Pembelajaran Jarak Jauh ( PJJ ) Belajar Dari Rumah ( BDR ) Dalam Jaringan ( DARING ) Online dan Luring.

Dalam kondisi darurat ini, kemasan muatan pembelajaran BDR, seharusnya akan sarat dengan penguatan literasi dan karakter. Konten diajarkan, selain untuk mengembangkan pengetahuan siswa (rote learning), juga digunakan sebagai medium dalam menumbuhkan dan memperkuat kemampuan literasi dan karakter. Sebagai sebuah aktivitas pembelajaran formal, penilaian tetap harus dilakukan. Namun, penilaian BDR dilakukan bukan untuk menentukan standar pencapaian (attainment level) atau kepentingan nilai (assigning grade) semata. Penilaian dalam BDR dilakukan mestinya dengan tujuan untuk membantu siswa agar dapat menemukan cara belajar yang lebih baik bagi dirinya pada setiap subjek yang dipelajari/diajarkan. Penilaian semacam ini disebut dengan penilaian formatif, yakni skor/nilai hasil sebuah aktivitas penilaian bukanlah standar pencapaian ataupun tujuan proses pembelajaran. Karena jika kita menggunakannya sebagai tujuan proses pembelajaran, nilai sesungguhnya yang merupakan ukuran dari status pembelajaran akan hilang dan justru mendistorsi proses pembelajaran yang diharapkan (Rogertitcombe: 2015).

Untuk tujuan ini, berbagai metode penilaian bisa digunakan, baik berupa penilaian proyek, penilaian portofolio, extended essays, dan bentuk penilaian lainnya yang relevan dengan tujuan pembelajaran. Teknologi pembelajaran Pengalaman pengelolaan pendidikan dalam kondisi darurat sekarang ini, hendaknya dapat menumbuhkan kesadaran kolektif kita sebagai bangsa akan pentingnya teknologi pembelajaran guna mewujudkan pendidikan bermutu dan berkeadilan. Konsep cyber schools dan/atau blended learning, termasuk penilaian disruptif (disruptive assessments), yang sudah banyak digunakan pada sejumlah sekolah/perguruan tinggi di mancanegara, hendaknya dijadikan kajian serius, konsisten, dan terukur oleh para pengendali kebijakan pendidikan pada tingkat nasional dan daerah. Kenyataan, beberapa akademisi akan memiliki kesempatan untuk secara kritis terlibat dalam teori, penalaran pedagogis dan desain pembelajaran yang terkait dengan pendidikan daring dan jarak jauh ini. Sementara itu, guru juga sudah perlu untuk melakukan perbaikan dengan cepat sehingga tak lagi gagap dan memungkinkan pembelajaran daring dan jarak jauh dapat berjalan sebagaimana layaknya. Menyelenggarakan pendidikan daring dalam banyak kasus masih berupa kuliah atau seminar, dengan melibatkan kelompok-kelompok besar individu, semua menghadiri ruang yang sama, pada saat yang sama, tetapi mereka tidak serta-merta terlibat satu sama lain. Pengajaran yang lebih baik melibatkan penilaian formatif, dan ini tidak harus ditandai dengan kerja keras. Teknik mempertanyakan, baik sinkron dalam hal streaming jarak jauh maupun asinkron dalam fasilitasi 
berbasis teks, yang memberikan bukti kepada guru/dosen untuk merespons dan menunjukkan arah pembelajaran bisa jauh lebih berharga.

Pembelajaran selanjutnya melibatkan siswa berkomunikasi satu sama lain, dengan kegiatan terstruktur antara mode transmisi, kolaborasi dan aplikasi. Ini semua bisa terjadi menggunakan teknologi yang tersedia sekarang dengan platform live-casting, dokumen kolaboratif, ruang dan aplikasi bersama (Matt Cornock: 2020).

Keadaan terkini dari teknologi informasi dan komunikasi tidak secara otomatis menciptakan lingkungan belajar yang inovatif dan berkualitas. Untuk membenarkan penggunaannya di kelas, mereka perlu menambahkan nilai dalam bentuk pada peningkatan motivasi dan keterlibatan siswa.

Pandemic COVID-19 secara tiba-tiba mengharuskan elemen pendidikan untuk mempertahankan pembelajaran secara online. Kondisi saat ini mendesak untuk melakukan inovasi dan adaptasi terkait pemanfaatan teknologi yang tersedia untuk mendukung proses pembelajaran (Ahmed et al., 2020). Praktiknya mengharuskan pendidik maupun peserta didik untuk berinteraksi dan melakukan transfer pengetahuan secara online. Pembelajaran online dapat memanfaatkan platform berupa aplikasi, website, jejaring social maupun learning management system (Gunawan et al., 2020). Berbagai platform tersebut dapat dimanfaatkan untuk mendukung transfer pengetahuan yang didukung berbagai teknik diskusi dan lainnya.

Kerja keras para guru dan dosen selama ini sungguh patut diapresiasi. Di tengah pembatasan sosial akibat wabah covid-19, kita harus tetap semangat mengejar dan mengajar ilmu pengetahuan. Hampir tidak ada yang menyangka, wajah pendidikan akan berubah drastis akibat pandemi covid19. Konsep sekolah di rumah (home-schooling) tidak pernah menjadi arus utama dalam wacana pendidikan nasional. Meski makin populer, penerapan pembelajaran online (online learning). kebijakan physical distancing untuk memutus penyebaran wabah, memaksa perubahan dari pendidikan formal di bangku sekolah menjadi belajar dari rumah, dengan sistem online, dalam skala nasional. Bahkan, ujian nasional tahun ini terpaksa ditiadakan. Tantangan pendidikan Sistem pendidikan online pun tidak mudah. Di samping disiplin pribadi untuk belajar secara mandiri, ada fasilitas dan sumber daya yang mesti disediakan. untuk pendidikan jarak jauh, ini banyak keluhan orangtua murid dan juga tenaga pendidik yang kesulitan, baik dalam menyediakan perangkat belajar seperti ponsel dan laptop maupun pulsa untuk koneksi internet. Dengan kata lain, sistem pembelajaran online ini berpotensi membuat kesenjangan sosial ekonomi yang selama ini terjadi, menjadi makin melebar saat pandemi.

Berdasarkan uraian tersebut, maka dilakukan review artikel dengan tujuan penelitian untuk memberikan tinjauan umum terkait pembelajaran online pada masa pandemic COVID-19 di Indonesia. Ini penting guna mengetahui implementasi dan dampak pembelajaran online pada peserta didik di Indonesia dengan harapan dapat memberikan informasi dan perbaikan dari kebijakan yang dilakukan. 


\section{KESIMPULAN}

Pembelajaran online memberikan kemudahan dalam memberikan transfer formasi pada berbagai situasi dan kondisi. Ragam manfaat dari kemudahan pembelajaran online didukung berbagai platform mulai dari diskusi hingga tatap muka secara virtual. Namun, hal ini perlu di evaluasi dan disesuaikan dengan kondisi setempat, mengingat kemampuan orang tua memberikan fasilitas pembelajaran online berbeda. Kuncinya adalah memaksimalkan kemampuan peserta didik belajar dalam kondisi pandemic seperti ini. 


\section{DAFTAR PUSTAKA}

Abidah, A., Hidaayatullaah, H. N., Simamora, R. M., Fehabutar, D., \& Mutakinati, L. (2020). The Impact of Covid-19 to Indonesian Education and Its Relation to the Philosophy of " Merdeka Belajar ." Studies in Philosophy of Science and Education,

1(1), 38-49. https://doi.org/https://doi.org/10.15408/sjsb s.v7i3.15104

Ahmed, S., Shehata, M., \& Hassanien, M. (2020). Emerging Faculty Needs for Enhancing Student Engagement on a Virtual Platform.

MedEdPublish, 1-5. https://doi.org/https://doi.org/10.15694/mep .2020.000075.1

Banggur, M. D. V., Situmorang, R., \& Rusmono.

(2018). Pengembangan Pembelajaran Berbasis Blended Learning pada Mata Pelajaran Etimologi Multimedia. JTP -

Jurnal Teknologi Pendidikan, 20(2), 152-

165. https://doi.org/10.21009/JTP2002.5 Bao, W. (2020). COVID-19 and online teaching

in higher education : A case study of Peking

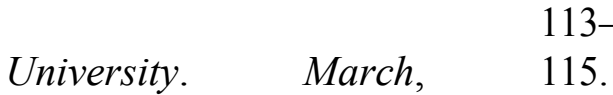

https://doi.org/10.1002/hbe2.19

1

Basilaia, G., \& Kvavadze, D. (2020). Transition to Online Education in Schools during a SARSCoV-2 Coronavirus (COVID-19) Pandemic in Georgia. Pedagogical

Research, 5(4). https://doi.org/10.29333/pr/7937 
Dai, D., \& Lin, G. (2020). Online Home Study Plan for Postponed 2020 Spring Semester during the COVID-19 Epidemic: A Case Study of Tangquan Middle School in Nanjing, Jiangsu Province, China. SSRN

Electronic Journal. https://doi.org/10.2139/ssrn.3555539

Dewi, W. A. F. (2020). DAMPAK COVID-19

TERHADAP IMPLEMENTASI PEMBELAJARAN DARING DI. 2(1), 55- 61.

Firman, \& Rahayu, S. (2020). Pembelajaran Online di Tengah Pandemi Covid-19. Indonesian Journal of Educational Science

(IJES), 2(2), 81-89. https://doi.org/10.31605/ijes.v2i2.659

Goldschmidt, K., \& Msn, P. D. (2020). The COVID-19 pandemic: Technology use to support the wellbeing of children. Journal of Pediatric Nursing, $x x x x, 3-5$. https://doi.org/10.1016/j.pedn.2020.04.013

Gugus Tugas Percepatan Penanganan COVID-19 Indonesia. (2020). Data COVID-19 Global dan Indonesia. https://covid19.go.id/

Gunawan, Suranti, N. M. Y., \& Fathoroni. (2020). Variations of Models and Learning Platforms for Prospective Teachers During 